\title{
Malaysia-Indonesia Cross-Border Governance: Is There a Trade-off between Security and Economic Development?
}

\author{
${ }^{1}$ Abdul Rahim Anuar \& ${ }^{2}$ Azhar Harun \\ ${ }^{1}$ School of International Studies, Universiti Utara Malaysia, Malaysia \\ ${ }^{2}$ School of Government, Universiti Utara Malaysia, Malaysia \\ abd182@uum.edu.my; h.azhar@uum.edu.my \\ DOI: https://doi.org/10.32890/jis2019.15.2 \\ Received:17/6/2019 \\ Revised: 4/9/2019 \\ Accepted: 2/10/2019
}

Published: 5/9/2019

\begin{abstract}
The National Security Council of Malaysia has declared the east coast of Sabah as the Eastern Sabah Security Zone (ESSZONE) to inhibit security threats and enhance security in the east coast of Sabah. This study employed an in-depth interview with the stakeholders involved in security governance and development in the study area. The selection of stakeholders was based on expert sampling. Secondary data relating to maritime economic activities were also used to reinforce the findings of the in-depth interview. The study areas were Tawau (Sabah) and Sebatik Island. Sebatik Island is divided into two regions; the northern region is owned by Malaysia and the south is owned by Indonesia. This paper examined the impact of ESSZONE's security policy toward economic activities in Tawau and Sebatik Island. The security policy implemented by the Eastern Sabah Security Command (ESSCOM) in Sabah's east coast has a negative impact on maritime economic activities in Tawau and Pulau Sebatik. Therefore, the government must re-evaluate the security measures in Tawau and Pulau Sebatik waters, and the curfew regulations in particular, because the security threat is lower and more manageable than in Sandakan, Tawau, Kunak, Lahad Datu, Semporna, and Kinabatangan, which form the hot spot area. Furthermore, the government should consider appropriate measures to balance the objectives of security and economic interests, depending on the level of security threat zones.
\end{abstract}

Keywords: Economic development, Sebatik Island, Tawau, trade-off, security.

\section{Introduction}

There will be no development without security and no security without development (United Nations, 2005). This means that a region will not progress and become developed when the territory is always threatened and has political or military conflicts following the absence of security. Therefore, security is necessary to develop a region. However, in the context of time, there is a trade-off between security and development. Security implemented today may cause the current development in associated regions to become stagnant. However, security over a region can lead to stability and peace in the future, thereby developing the 
related region positively. Therefore, this article discusses the relationship between security and development by considering ESSZONE, and Tawau and Sebatik Island (Sabah) as case studies.

The concept of security has mostly been associated with national security and external military threats to the nation state (Bernard, 1998). Currently, this narrow and traditional view has been broadened to consider the concept of human security or non-traditional security. Human security includes seven elements of security, namely economic security, health security, food security, environmental security, personal security, community security, and political security (Anderson, 2012).

In line with this, the concept of development has also progressed from just relating to economic growth and structural adjustment change to human development and sustainable development (Sumner \& Tribe, 2008). The sustainable development concept is development which meets the needs of the present without compromising the ability of future generations to meet their own needs. Sustainable development most often includes four dimensions which are ecological social economic, and (not always) political (Drexhage \& Murphy 2010).

Security threats, such as maritime piracy, kidnapping, smuggling, and human trafficking repeatedly occur along the coastal regions of east Sabah. 2013 marked a tragic event, when Sulu militants invaded Lahad Datu, thereby threatening the sovereignty of the country, triggering a host of security concerns to the public in Malaysia, and Sabah in particular. In realising the fact that the security threats were increasing in the eastern part of Sabah, the federal government declared the region, on 7 March 2013, a Special Security Area (SSA) to safeguard the sovereignty and security of the state's east coast. During the early establishment, the SSA only covered the districts of Kudat, Tawau, Kunak, Sandakan and Lahad Datu. On 25 March 2013, the federal government established the Eastern Sabah Security Zone (ESSZONE), covering 10 districts in eastern Sabah with an area of 1,734 kilometres from Kudat to Tawau. The associated regions included Kudat, Kota Marudu, Pitas, Beluran, Sandakan, Kinabatangan, Lahad Datu, Kunak, Semporna and Tawau. In the same year, the federal government also established the Eastern Sabah Security Command (ESSCOM), which was a new security enforcement agency for ESSZONE and created specifically to protect the sovereignty and security of the east coast, following the intrusion of Sulu terrorists in Lahad Datu. Moreover, security cooperation protocols with neighbouring countries, particularly Philippines and Indonesia, were implemented to combat terrorism and cross-border crimes.

Following the occurrence of kidnappings and attacks in tourist areas within the ESSZONE, a curfew was enforced on 16 July 2014 covering six districts of Sandakan, Tawau, Kunak, Lahad Datu, Semporna and Kinabatangan. Until today, the curfew still continues to be enforced involving all ESSZONE and territorial waters of the country, following kidnapping, terrorism and illegal immigration activities. 
The issue of maritime security at state level in Sabah was studied by Wan and Ramli (2009). They were of the view that the issue of security in Sabah occurs on a large scale and creates a safety concern to the country. Cross-border crime is often the case occurring in Sabah, such as smuggling, piracy, robbery and kidnapping, which may not be a new issue in Sabah, but nevertheless, it has become a national issue and requires urgent action from the government. The continual influx of illegal immigrants into Sabah is due to its geographical location, where it is exposed to two neighbouring countries, the Philippines and Indonesia.

Security issues have also increased the federal financial allocation to Sabah. Malaysia spent nearly RM6 billion to enhance security in the east coast of Sabah following Sipadan's border conflicts with Indonesia in 1991. In 2013, following the attack on Sabah by Sulu (Philippines) militants, the government spent more by setting up ESSCOM and improving border defence technology to protect the security of the country's territorial waters from foreign elements and human security threats.

Rasid et al. (2015) stated that social, political, and economic issues are characteristically cross-border in nature and consequently would have a negative impact on the security of neighbouring countries. This is clear with the political, social and economic disorder in southern Philippines that has affected the security of Sabah with the influx of illegal immigrants, smuggling of controlled and prohibited goods, piracy in local waters, and kidnapping of tourists. The findings by Rasid et al. (2015) also showed that the security issue of the coastal areas has given an impact on the socio-economic viability of the communities.

The study by Mak (2009), showed that Malaysia has faced the issue of security threats for more than 20 years, with repeated occurrences of piracy, smuggling and robbery in the Straits of Malacca and the Sulu Archipelago. In particular, Mak (2009) identified the important stakeholders in the local waters from the aspects of economy and safety, namely the fishing trawlers in Peninsular Malaysia, the barter-trade between the Philippines and Sabah, and piracy in the Straits of Malacca and Sumatera, Indonesia. Another issue that was highlighted was the problem of differing border water maps between neighbouring countries. This has led to disputes over maritime boundary that were not resolved and complicated the control of operations and safety by the authorities of the respective countries.

The illegal immigrant problem in Sabah this decade has given concern to the government and local communities because immigrants have led to high crime rates and threaten security in Sabah. Sabah waters are spacious and very porous, where its openness has led to the existence of many "backdoors" that have been favourable to outsiders to discretely enter Malaysia (Arvin \& Nurfazlina, 2015).

From the development perspective, Abdul Rahim (2015) in his study on the development of cross-border economy in Tawau (Malaysia) and Nunukan Island (Indonesia) found that the development concept in the border areas of these two countries is characteristically 
traditional. Malaysia and Indonesia consider the issues of defence and security to be more pertinent than issues of development. Poverty, which is among the human security issues, is higher in Nunukan Island as compared to Tawau, thus becoming a push factor for Nunukan residents to migrate and find employment in Tawau. In addition, most of the people of Tawau and Sebatik Island depend on maritime economy for their living. Thus, any security threat in the east coast can jeopardise the welfare of local residents, including those in Tawau and Sebatik Island.

\section{Methods}

This qualitative study employed in-depth interviews and was supported by secondary data and fieldwork in the research area. The in-depth interviews were conducted on selected respondents to analyse the impact and implementation of ESSZONE on economic development in Tawau and Sebatik Island. In-depth interviews offer the opportunity to capture rich, descriptive data about people's behaviours, attitudes and perceptions, and unfold complex processes.

The selection of respondents in this study was based on expert sampling. Expert sampling is a form of purposive sampling used when the research requires one to capture the knowledge rooted in a particular form of expertise. Thus, the eight respondents selected and interviewed, were a barter-trade trader in Tawau, a representative from the Sebatik Island Fishermen's Association (Tawau), a representative from the Tawau District Fishermen's Association, the Superintendent of District Fisheries Office, the General Manager of the Fishermen's Association Tawau (Tawau PKN), the Sabah Secretary of National Security Council, the Commissioner of Police Staff, and the Consulate of the Republic of Indonesia Tawau. All respondents were selected based on their functions and their roles related to the issue under review.

Secondary data sources were also obtained through interviews with the National Security Council (NSC), the Tawau Royal Malaysian Customs, the Immigration Department of Malaysia (Sabah), the Tawau Area Fishermen's Association (PNK), the Department of Tawau Fisheries District Office, the Consulate of the Republic of Indonesia (Tawau), a representative of the barter-trade traders and Tawau fishermen in Tawau and Sebatik Island, the Annual Statistics of Sabah and the Sabah External Trade Statistics. Sources of information about security threats were obtained from the Eastern Sabah Security Command.

Secondary data related to the maritime economy were collected for supporting the information obtained from the primary sources. The secondary data were gathered from the Department of Statistics, which publishes the Annual Statistics of Sabah and the Sabah External Trade Statistics. Information about security threats to the east coast of Sabah were obtained from the mainstream media and websites, especially the Eastern Sabah Security Command portal. 
The findings of the in-depth interview were supported by secondary data to reinforce the argument and the validity of the information from the interview. Fieldwork was also conducted in the study area to evaluate the present economic activity in the study area.

The analysis of the interviews with the stakeholders was divided into (a) the community involved in maritime economic activities and (b) the government that implements the security policy. The study results were divided into two perspectives, i.e. (a) barter-trade and security measures and (b) local and national security.

\section{Results}

Many security threats occur repeatedly along the east coast of Sabah, especially in the ESSZONE territory. The ESSZONE was established on 25 March 2013 due to the intrusion by Sulu militants in Sabah. ESSZONE covers 10 districts in Sabah's east coast between Kudat and Tawau; including Kudat, Kota Marudu, Pitas, Beluran, Sandakan, Kinabatangan, Lahad Datu, Kunak, Semporna and Tawau with a beach area spanning 1,734 kilometres. Regulatory agencies face the challenge of maintaining security in the region as cross-border crimes often occur in the waters off the east coast of Sabah.

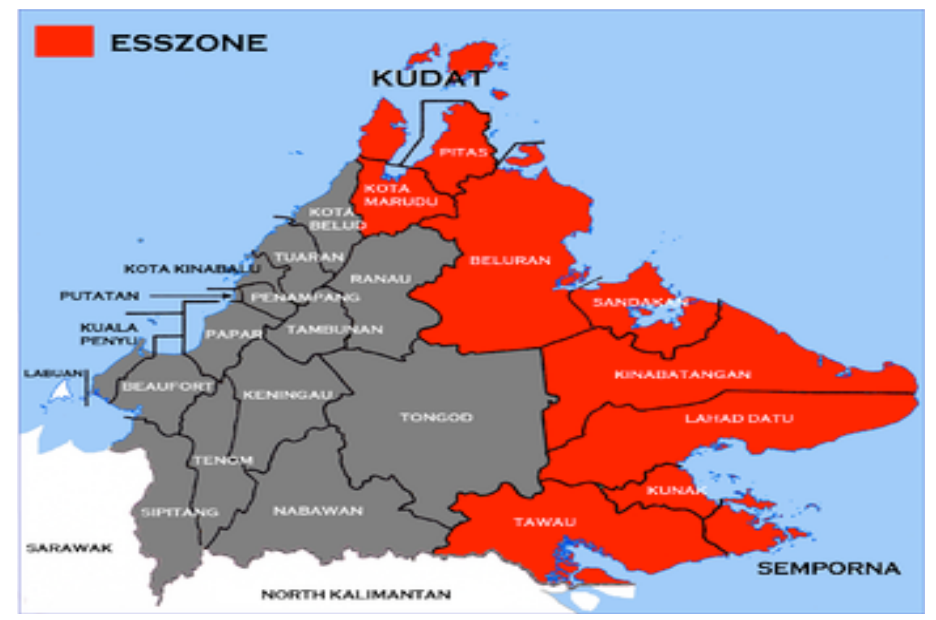

Figure 1. ESSZONE Area

Source: The Eastern Sabah Security Command (ESSCOM), Malaysia 


\section{Sulu Militants}

The Sulu militant attack was one of the most critical NTS threats to Malaysia in dealing with terrorism at the regional level, in addition to the Malaysia-Indonesia confrontation at the start of the 1960s. Malaysia had to use all security assets to defeat the Sulu militant groups. The Sulu militant aggression was carried out by the heirs of the Sultanate of Sulu, Jamalul Kiram III, on 11 February 2013 in the Tanduo village in Lahad Datu, Sabah. The militant group that performed the intrusion into Lahad Datu was headed by Azzimudie Kiram, who claimed that they were not militants, but Royal Security Forces of the Sultanate of Sulu and North Borneo attempting to enforce the Sulu people's right to recover Sabah (Malaysiakini, 2013 March).

This incident led to casualties on both sides. On the Malaysian side, nine members of the Malaysian defence fell in the field of battle, while 68 members of the Sulu militants were killed in clashes with security forces. The Sulu conflict in Sabah ended in March 2013 and was followed by the establishment of the legal basis to establish ESSZONE and ESSCOM (Bernama, 2013 December, 16).

\section{Kidnapping}

Prior to the terrorist attacks by the Sulu militants, maritime security threats that were often found included piracy in the waters off the east coast of Sabah. Piracy or better known as "mundu" by the local people of Sabah is a cross-border crime that often occurs despite increased security efforts in the ESSZONE region. In fact, piracy not only involved assault or armed robbery by pirates on local boats, but they also could take more aggressive action by attacking police stations and carrying out grand scale robbery such as in the town of Semporna in 2010 (Ramli, 2004).

Kidnapping incidents also occurred on 15 November 2013, when there was an ambush by Filipino pirates on Bom Island that killed Hsu Li Min, a Taiwanese citizen, and Chang Ai Wei was held hostage and released in December 2013 (The Star, 2014 December 23). Then, on 2 April 2014, Chinese tourist Gao Hua Yuan and Filipino resort worker Marcy Darawan were kidnapped in the Singamata Reef Resort Semporna, and released on 30 May the same year, while a second incident occurred on 6 May of the same year. This time the victim was Yang Zai Lin, a 34-year old Chinese national who was kidnapped in Pulau Baik, Lahad Datu. The victim was rescued after 65 days and found in the forest area of Patikul, in the Jolo archipelago which is also a stronghold of the Abu Sayyaf splinter group (Utusan Malaysia, 2016 May 3).

On 16 June 2014, another kidnaping incident involved a caged-fish breeding centre owner, Chan Sai Chiun, 32 years old, and a Filipino worker in his 20s. Both were released on 9 December 2014 (Sinar Harian, 2014 June 16). The victims were abducted by two armed men in Kampung Sapang Air, Kunak. On 12 July 2014, the marine police force in Mabul 
Island, Semporna, was ambushed by kidnappers in the ESSZONE. Constable Zakia Aliep was the new kidnapping victim of the group. The victim was released on 7 March 2015 after a negotiation between the government and the kidnappers, but not before fellow police officer Corporal Ab. Rajah Jamuan, 32 years old, was shot dead in the incident (Berita Harian, 2015 March 7).

Repeated kidnappings in Sabah occurred on 14 May 2015 when two local people were abducted by the Abu Sayyaf in the Ocean King Restaurant, Sandakan. The victims were Thien Nyuk Fun, 50, who was the manager of the restaurant and her son, Bernard Ghen Ted Fen, 39, who was an electronics consultant in Cambodia (Astro Awani, May 25, 2015). Thien was released on 9 November 2015; however, Bernard Ghen was beheaded on 17 November 2015 (Sinar Harian, 2015 December 19). The mastermind behind the kidnapping in ESSZONE and the four abduction cases was believed to be the "Muktadir Brothers" (The Star, 2014, June 22).

\section{Smuggling}

Sabah's geographical position, which is near Mindanao (Philippines) and Nunukan Island (East Kalimantan, Indonesia), have led to continuous occurrences of smuggled goods. For example, on 2 October 2015, the Malaysian Maritime Enforcement Agency (APMM) foiled an attempt to smuggle gas and oil to neighbouring countries through the waters off Tawau (My News Hub, 2015 October 2). Smuggling of subsidised items from Malaysia to neighbouring countries, particularly Kalimantan (Indonesia), has become more frequent and widespread. Subsidised items such as cooking gas, petrol and diesel, rice, sugar, flour, eggs, and chicken are items that are often smuggled out of the country because in this country these items can be found at cheaper prices (Astro Awani, 2013 July 1).

On 16 January 2015, the Royal Malaysian Customs Department seized 26 kilograms of "syabu" or cocaine, worth nearly RM5 million, in Tawau airport (Berita Harian, 2015 January 20). In 2014, a total of 480 cases of smuggled cigarettes and 103 cases of other smuggled goods occurred in the ESSZONE waters during the January-June period, as was recorded by the Sabah Customs Department (Sinar Harian, 2014 August 11).

\section{Illegal Immigrants in Sabah}

The number of illegal immigrants in Sabah is not known because there is no official data recorded by the government. However, the data related to the number of illegal immigrants deported from Sabah can be used as an indicator of the number of illegals in Sabah. For the period 2014 to May 2016, 54,941 illegal immigrants in Sabah were deported to their countries of origin. ESSCOM also improved the operations of tracking illegal immigrants in the area-Tawau, Semporna, Kunak, Lahad Datu, Kinabatangan, Sandakan, and Beluranand since 2015 until 4 May 2016, it had carried out 1,823 ESSCOM enforcement operations and successfully detained 11,688 illegal immigrants (Bernama, 2016 May 16). 


\section{Curfew in ESSZONE}

The curfew was implemented on 19 July 2014, which was a security policy established by the government especially for the ESSZONE region (ESSCOM, 2014 July 19). The curfew conditions were:

- Individuals, except security personnel and exempted individuals, can be in a predetermined area from $6.00 \mathrm{pm}$. to $6.00 \mathrm{am}$.

- Individuals exempted from the curfew include the "Yang DiPertuan Agong", "Raja", "Yang DiPertua Negeri", and any member of the Malaysian Navy, Airforce, and Army who is on duty (according to Section 31(3) Police Act 1967).

- Individuals other that the authorities that want to enter or pass through the curfew region need to obtain a Curfew Exemption Permit from the Head of Police in the respective region.

- $\quad$ Any individual found in areas that have been declared as being under airfew during the established times can be detained without a warrant and can be put on trial in court.

- $\quad$ Enforcement members can obtain a mandate to arrest any individual that does not adhere to the curfew in Section 31 (2) Police Act 1967.

- $\quad$ Enforcement members are allowed to use firearms in accordance with the requirements and provisions of the law.

The curfew was extended by the Sabah Polis Commissioner to 12 December 2018. This was to ensure the Sabah's waters would not be invaded by terrorists who could threaten the security of international researchers conducting research, as well as tourists present at the resort islands. It was also to ensure the safety and well-being of Sabahans in the ESSZONE. The curfew would also facilitate enforcement, and monitoring of boat movements, while the presence of security vessels would create a sense of security for chalet operators and fishermen in the area.

\section{Barter-trade and Security Measure Perspective}

According to a barter-trade trader with more than 20 years of experience in the industry, the government's proposal to embargo barter-trade activities in Sabah-Mindanao and SabahKalimantan to combat repeating cross-border crime should be revaluated. However, from the government's perspective, it is a proactive step in addressing all the smuggling and kidnappings that occur in the ESSZONE.

Barter-trade in Sabah's east coast is carried out in the ports of Sandakan and Tawau, which act as the main entrance for merchants from Mindanao and east Kalimantan. Sabah's major imports are from Indonesia and southern Philippines such as cigarettes, high value marine products, timber, kitchen utensils, and others because they are relatively cheaper. Table 1 shows the barter-trade business in favour of Sabah with an average trade surplus for the period 2011-2015 of RM124 million (Sabah-Indonesia) and RM25 million (SabahPhilippines). 
Table 1

Sabah barter-trade with Indonesia and Philippines through Tawau Port for the period 20112015 (RM million)

\begin{tabular}{lcccccc}
\hline & \multicolumn{3}{c}{ Indonesia } & \multicolumn{3}{c}{ Philippines } \\
\cline { 2 - 6 } Year & Import & Export & $\begin{array}{c}\text { Trade } \\
\text { Balance }\end{array}$ & Import & Export & $\begin{array}{c}\text { Trade } \\
\text { Balance }\end{array}$ \\
\hline 2011 & 26.0 & 190.0 & 164.0 & 0.1 & 31.0 & 31.1 \\
2012 & 31.0 & 251.0 & 220.0 & 20.0 & 11.0 & 31.0 \\
2013 & 2.8 & 0.0 & -2.8 & 0.0 & 0.6 & 0.6 \\
2014 & 30.7 & 114.0 & 83.3 & 0.0 & 25.3 & 25.3 \\
2015 & 28.9 & 184.9 & 156.0 & 0.1 & 35.7 & 35.8 \\
average (2011-2015) & 23.9 & 148.0 & 124.1 & 4.0 & 20.7 & 24.7 \\
\hline
\end{tabular}

Source: Royal Malaysian Customs Department, Tawau

Barter-trade provides a very high positive impact on the socio-economic development of the people in the three countries because it creates economic activities in marginalised and rural areas in the respective countries. Among barter-trade traders, this step would have a negative impact on the business of barter-trade in Sabah. The barter-trade business has improved bilateral relations between Sabah-Mindanao and Sabah-Kalimantan. In fact, the spill-over effects of the barter-trade economy is clearly observed in the creation of new jobs and business opportunities related to the maritime industry in Tawau.

Cross-border crimes, such as smuggling in Sabah's east coast waters, are done by unscrupulous individuals who were intent on earning huge profits without paying taxes to the government of Malaysia. Smuggling is done alone without involving actual barter-trade traders.

Barter-trade is controlled by the Royal Malaysian Customs and the exchange of export and import goods is carried out in a special area called the Tawau Goods Exchange Centre adjacent to Tawau port. If any ship from foreign countries (especially from Indonesia and Philippines), that carries trade products and is not anchored in the Tawau Goods Exchange Centre, it will be charged as smugglers under the Malaysian Trade and Barter-trade laws. However, wet and perishable items such as fish and other marine products are exempted from anchoring at the Tawau Goods Exchange Centre and are allowed to berth at the fishery jetties in Tawau.

Increased security measures undertaken by the government, in fact, does not affect the barter-trade activity. Instead, a barter-trade ban would affect trade and barter activities which 
would be detrimental to Sabah. Therefore, the government should identify the root cause of security threats along the east coast of Sabah. This view by the barter-trade representative with experience of more than 20 years was shared by the representative of the Tawau Sebatik Island Fishermen. Following the implementation of security and the curfew, fishermen are not allowed to enter other regional fishery zones and can only catch fish in their own zones, namely Zone A (Tawau).

\section{Maritime Economic Activity}

Security threat to the Tawau district is less than in other regions, especially Semporna, Kunak, Lahad Datu and Sandakan, which are often referred to as the Hot Zone. Therefore, the lack of NTS threat does not affect the maritime economic activities in Tawau. Conversely, security measures and curfews imposed on all areas do affect maritime economic activities in Tawau. The curfew from 6am to 6pm was enacted on 16 July 2014 covering six districts of Sandakan, Tawau, Kunak, Lahad Datu, Semporna and Kinabatangan.

There are 1,515 fishermen in Tawau and of that number, 98\% are Malays (Persatuan Nelayan Kawasan Tawau, 2016). Curfews have a significant impact on the income of fishermen because they cannot go out during the time of curfew and cannot fish in other zones, except in their own designated zone. Due to the increasing number of complaints from fishermen in ESSZONE, the government has given an allowance of RM300 per month to small fishing operations and RM250 per month for trawlers, as well as reducing accident insurance with a deduction of RM100 per annum. In addition, the Fishermen's Area Association also provides assistance in terms of repairing damaged equipment and improving the infrastructure for the fishermen.

Concerns expressed by the representative of the Tawau Fishermen's Association were also raised by the representative of the Sebatik Island Fishermen Association that has 626 members (Persatuan Nelayan Pulau Sebatik, 2015). The curfew from 6am to 6pm every day has affected the income of the fishermen, who are also low-income earners and can be categorised as poor. They hoped that the government can quickly resolve the security problems in the coastal waters of east Sabah to enable them to catch fish as usual.

Moreover, Tawau waters are in a situation that is more secure, especially for maritime economic activities. This is unlike in Semporna, Kunak, Lahad Datu and Sandakan, areas which form the Hot Spot of criminal activities including kidnapping, piracy, robbery, threats of Sulu attacks, weapons and illicit goods smuggling, and other cross-border crimes. Thus, economic activities in these areas are affected by the emergence of these non-traditional security threats.

In recapitulation, the security policy implemented by the government in Sabah's east coast has a negative impact on maritime economic activities in Tawau. Concerns were raised by barter-trade traders and representatives of the Association of Fishermen (Tawau and Sebatik Island), both of whom were in agreement with the representatives of the Tawau Area Fishermen's Association (PNK Tawau) and the Superintendent of Tawau District Fisheries 
Office. Both of the latter agencies also assisted fishermen in the form of financial aid to continue with their daily lives. However, in terms of policy implications, the government must re-evaluate the security measures in Tawau waters and the curfew regulations in particular, because the non-traditional security threat is lower and more manageable than in Sandakan, Tawau, Kunak, Lahad Datu, Semporna and Kinabatangan, which form the hot spot area.

\section{Local and National Security}

The view adopted by the business community involved is in very stark contrast to the government's view. The government must prioritise security and sovereignty. If this can be maintained, then it acts as a platform for developing the economy of the country and the people. This is because political stability is closely related to the country's development.

From the government is perspective, especially the National Security Council, the abolition of the barter-trade is associated with wooden boats carrying goods from MindanaoSandakan and East Kalimantan-Tawau to trade, but they also take the opportunity to smuggle prohibited goods such as drugs, firearms, and carry out human trafficking. In other words, irresponsible individuals perform cross-border criminal activities under the name of bartertrade activities.

This has prompted the government to embargo the business of barter-trade with a view of combating cross-border crimes. However, barter-trade traders who comply with the law are also affected by these security measures taken by the government. With this in view, the government should be ready to hold dialogue sessions with barter-trade traders to resolve their problems and predicament. At the same time, agencies at the Sabah state level, such as the State Economic Planning Unit, the Sabah Economic Development and Investment Authority (SEDIA), the Fisheries Development Authority, the Federal Agricultural Marketing Authority (FAMA), and the Department of Agriculture, should collectively take the initiative to assist target groups affected by the security measures implemented by the government.

From the view point of the government of the Republic of Indonesia (RI), the bilateral trade relations of Sabah-East Kalimantan and barter-trade were important from the very beginning, which led to the signing of several important agreements, namely the Border Trade Agreement 1970 and the Border Cross Agreement 2006. RI also supports Malaysia in the implementation of measures to improve security in the waters off the east coast of Sabah with the view to combat cross-border crimes. This will also assist merchants from East Kalimantan to do barter-trade activities with Tawau dealers formally and without hindrance in the future.

However, RI focuses more on taking care of the welfare of the Indonesian workers (TKI) employed in Sabah and Sarawak, compared to barter-trade activities. This is because the Tawau-Nunukan barter-trade traders comply more with the barter-trade rules and regulations 
than the Filipino Sandakan-Mindanao traders that take advantage of barter-trade activities to perform cross-border crimes.

The Indonesian consulate in Tawau is also aware that the implementation of security measures by ESSCOM in ESSZONE would affect the Tawau-Nunukan bilateral trade and the revenue from the bilateral trade would decline. However, the positive effect is even greater in the long-term, where the trade routes in the east coast of Sabah, including Tawau, can be monitored safely for non-traditional security threats, such as smuggling of illegal goods such as drugs and weapons, and human trafficking.

In summary, the Malaysian government needs to give priority to security over economic interests in view of the uncertain security environment which could affect sovereignty and national security in the long term. However, for the communities involved in maritime economic activities, economic welfare takes precedence in order to maintain their living standards.

\section{Conclusion}

Threats from terrorism still remain high in Sabah. This is due to the geographic position of Sabah with its neighbouring countries, namely Indonesia and the Philippines. Crossborder criminals will travel along the east coast, while some enter Sabah at transit points to carry out their criminal activities. To protect the country from any unwanted threats, all government agencies and security forces must play their part to protect and to prevent such threats from happening. On the whole, ESSCOM has managed to increase the level of security in the waters off the east coast of Sabah, especially in the Hot Spot areas, and thus cross-border crime has been reduced significantly. In the long term this can regenerate economic activity when the level of security in the maritime waters can be fully guaranteed. However, economic activity in Tawau (including Sebatik Island), which is a region that faces less security threats, is adversely affected by the security measures implemented by the government, especially the curfew. The income of the fishermen in Tawau and Sebatik Island has decreased due to the curfew that limits the time and the fishing zones of these fishermen. However, an emergency plan to help them has been implemented by the agencies concerned with the welfare of these fishermen. The government must prioritise security, while the community gives priority to economic activities for their livelihood. Therefore, the government should consider appropriate measures to balance the objectives of the security and development interests, depending on the level of security threat.

\section{Acknowldgement}

The authors like to thank Universiti Utara Malaysia for providing funding to do the study on Program Transformasi Ekonomi Pekan Sempadan Di Persempadanan Malaysia-Indonesia/ Thailand/Brunei/Ke Arah Pembangunan Ekonomi Lestari Dan Berpendapatan Tinggi (FRGS 12185). 


\section{References}

Abdul Rahim Anuar. (2015). Rubrik pembangunan pekan sempadan Malaysia-Kalimantan: Tawau-Pulau Nunukan. Journal of Borneo Social Transformation Studies (JOBSTS), Vol. 1, No. 1:16. Universiti Malaysia Sabah.

Anderson, N. A. (2012). Redefining international security: Bringing intent back in. Josef Korbel Journal of Advanced International Studies, 4 (Summer), 27-47.

Arvin Tajari \& Nurfazlina Affendi. (2015). Illegal immigrant and security crisis in Sabah (Malaysia). E-Proceeding of the International Conference on Social Science Research (ICSSR), 8-9 June 2015. Melia Hotel Kuala Lumpur Malaysia.

Astro Awani.(2013, July 1). KDN memperluaskan usaha pencegahan penyeludupan Sabah dan Sarawak. Astro Awani. Retrieved from http://www.astroawani.com/

AstroAwani. (2015, May 5). Dua individu diculik lelaki bersenjata di Sandakan. Astro Awani. Retrieved from http://english.astroawani.com/

Berita Harian. (2015, January 20). Kastam Tawau rampas syabu bernilai RM4.9 juta. Berita Harian. Retrieved from http://www.bharian.com.my/node/30462

Berita Harian. (2015, March 7). Lans Koperal Zakiah Aleip dibebaskan hari ini. Berita Harian. Retrieved from http://www.bharian.com.my/node/39136.

Bernama. (2013, December 16). Pencerobohan Lahad Datu catat sejarah hitam negara. Bernama. Retrieved from http://www.sinarharian.com.my/.

Bernama. (2015, May 16). Over 50,000 illegal immigrants in Sabah deported between 2014 and May 2016: Zahid. Bernama. Retrieved from http://www.nst.com.my/

Bernard, I. F. (1998). What is security? Why the debate matters. National Security Studies Quarterly, Vol.4, No. 4, 1-18.

Drexhage, J., \& Murphy, M. (2010). The origins of sustainable development: Sustainable development: From Brundtland to Rio 2012. New York: United Nations.

ESSCOM (2014, July 19). Curfew off the east coast of Sabah beginning 6pm today. ESSCOM. Retrived from https://esscom.gov.my/

Harian Metro. (2016, April 1). Perintah berkurung masuk fasa ke-40. Harian Metro. Retrieved from http://www.hmetro.com.my.

Mak Joon Num. (2009). Pirates, barter traders, and fishers: Whose rights, whose security? User Conflicts and Maritime Non-traditional Security in Malaysian Waters, 19-28. Retrieved file:///C:/Users/Del1/Downloads/02_Joon.pdf.

Malaysiakini. (2013, March 2). Kronologi pencerobohan kumpulan bersenjata di Lahad Datu. Malaysiakini. Retrieved from https://www.malaysiakini.com/news/.

My News Hub. (2015, October 2). APMM patahkan penyeludupan gas, minyak di Tawau. My News Hub. Retrieved from http://www.mynewshub.cc/

Persatuan Nelayan Kawasan Tawau. (2016). Statistik nelayan di Tawau. Tawau: Persatuan Nelayan Kawasan Tawau.

Persatuan Nelayan Pulau Sebatik. (2015). Statistik nelayan di Pulau Sebatik. Tawau: Persatuan Nelayan Pulau Seabatik.

Ramli Dollah. (2004). Lanun atau mundu Di Sabah. Jati, Bilangan 9:171-188. Retrieved from http://repository.um.edu.my/. 
Rasid Mail, Baszley Bee Basrah Bee, Saat Ag Damit, \& Ab Nasir Roslan. (2016). Isu keselamatan perairan pantai timur Sabah: Kelangsungan sosio-ekonomi masyarakat pesisir. Seminar SASSREC 1: Sempadan \& Keselamatan Sabah, 25-26 Februari 2015, Pusat Pengajian Strategik dan Keselamatan Sabah (SASSREC), Unit Kajian Remote Sensing dan GIS (CERGIS), Pusat Penyelidikan Pulau-Pulau Kecil (SIRC), Dewan Bankuasi UMS.

Sinar Harian. (2014, August 11). 480 kes penyeludupan rokok di Sabah bagi Jan-Jun. Sinar Harian. Retrieved from http:/www.sinarharian.com.my/

Sinar Harian. (2015, December 19). Kepala dijumpai di Jolo sah milik Bernard Then. Sinar Harian. Retrieved from http:/www.sinarharian.com.my/

Sinar Harian; (2014, June 16). Mangsa culik: Jangan kacau isteri saya. Sinar Harian. Retrieved from http://www.sinarharian.com.my/

Sumner, A., \& Tribe, M. (2008). What is development: Development studies theories methods in research and practice. London: Sage Publications.

The Star. (2014, December 23). Claims of ransom payout for captive. The Star. Retrieved from http://www.thestar.com.my/news/nation/

The Star. (2014, June 22). Muttadir kin mastermind behind kidnaps? The Star. Retrieved from http://www.thestar.com.my/news/nation/

United Nations. (2005). In larger freedom: Towards development, security and human rights for all. Report of the Secretary-General, New York. Retrieved from http:// www.un.org/largerfreedom/contents.htm

Utusan Malaysia. (2016, May 3). Memburu penculik kumpulan Abu Sayyaf. Utusan Malaysia. Retrieved from http://www.utusan.com.my/

Wan Shawaluddin \& Ramli Dollah. (2008). Isu-isu keselamatan Sabah dan impak kepada Malaysia. Jati, Bilangan 13:49-63. 